\title{
Revista Argentina de
}

\section{editorial}

En la primera edición del año 2020, se presentan datos del Registro Argentino de Miopatías Inflamatorias de la Sociedad Argentina de Reumatología. En esta ocasión, el registro nos aporta hallazgos significativos en cuanto a los métodos diagnósticos en las miopatías inflamatorias autoinmunes.

García Salinas R. et al presentan un estudio en 106 casos donde se preguntan si los entrenamientos de resonancia magnética en espondiloartritis sirven para mejorar la performance de los reumatólogos para el reconocimiento de secuencias y lesiones. Este estudio está prologado por la Editorial II del Dr. Xenofon Baraliakos.

Se presenta una puesta al día sobre nuevas recomendaciones para la densitometría ósea pediátrica, posición oficial ISCD 2019, por Brance ML.

Se presentan 4 casos del Hospital Pirovano de CABA incluidos en el Registro de Miopatías inflamatorias de la
Sociedad Argentina de Reumatología (SAR).

Se presenta un caso de polineuropatía desmielinizante inflamatoria crónica como forma de presentación de lupus eritematoso sistémico. y revisión de la literatura, por Alonso C. et al, del Hospital de Córdoba, UNC.

Se presenta un caso clínico y revisión de la literatura de policondritis asociada a enfermedad por IgG4, por Gallo J. et al, que vale la pena leerlo para estar atento a la aparición de este tipo de casos.

Por último, se presentan 4 casos de Cavidades pulmonares en Lupus Eritematoso Sistémico, con revisión de todos los casos publicados a nivel mundial, por el equipo de Paira S.

\section{Darío Scublinsky \\ Editor}

\section{editorial II}

Spinal inflammation is one of the most important features of ankylosing spondylitis (AS), as it determines spinal pain and dysfunction. Currently, spinal inflammation is mainly assessed through patient reported outcomes and it may be subject to individual factors and interferences. Magnetic resonance imaging (MRI) has demonstrated its value in detecting bone oedema and inflammation and it has been included in the new classification criteria of the Assessment of Spondyloarthritis international Society (ASAS). Gradually, MRI was imposed due to its greater sensitivity compared to $\mathrm{X}$-Rays, especially in early lesions and in clinical trials. Although MRI has not entirely supplanted conventional radiology-among other reasons, due to its high cost and the time needed to perform and read-, it is important to know how to evaluate MRI images in AS. This is especially relevant in order to conduct research and to understand the results of clinical studies, and also in order to be able to apply this knowledge to individual patients in whom a MRI is clinically justified.

The study currently published by García Salinas et al provides valuable information about the effectiveness of a calibration exercise on reading spinal MRIs in patients with AS in general and on the use of a systematic training for this, in particular. One main deduction is that the calibration exercise increased the number of lesions detected by the initially inexperienced readers. The overall performance of the participating physicians increased after the systematic training. The Authors could interpret this as if the training had increased the sensitivity of the rheumatologists in reading spinal MRIs of patients with active AS.

In conclusion, a systematic training of rheumatologists in interpreting MRIs of patients with axSpA seems to be a reliable method even in, initially, inexperienced readers; calibration training may improve feasibility and increase the number of lesions detected for the correct identification of our patients in daily practice.

\section{Xenofon Baraliakos}

Rheumazentrum Ruhrgebiet, Ruhr-University Bochum, Germany 